СТАВСКАЯ Юлия Вацлавовна - кандидат экономических наук, доцент кафедры менеджменту внешнеэкономической деятельности, гостиничноресторанного дела и туризма Винницкого национального аграрного университета (21008, г. Винница, ул. Солнечная, 3, e-mail: usv.urf@ukr.net).

УДК: 338.48 / 332.1

DOI: 10.37128/2411-4413-2021-1-4

СОЦАЛЬНОЕКОНОМІЧНІ АСПЕКТИ РОЗВИТКУ МІЖНАРОДНОГО ТУРИЗМУ ПІД ВПЛИВОМ ГЛОБАЛІЗАЦІЙНИХ ЧИННИКІВ

\author{
ГОЛОВНЯ О. М., \\ доктор економічних наук, \\ доцент кафедри менеджменту \\ зовнішньоекономічної діяльності, \\ готельно-ресторанної справи та туризму, \\ Вінницький національний аграрний університет \\ (м. Вінниця)
}

Простежено вилив глобалізації на соціально-економічний розвиток світу та України. Негативні наслідки процесу глобалізації полягають у тому, щуо він став величезним викликом для людства. На думку автора, до найбільших загроз сучасного світу варто віднести: потік надмірної інформачії, який часто перетворюється на інформаційні атаки; міжнародний тероризм, який загрожує міжнародному туризму та безпечному соціально-економічному розвитку багатьох країн; негативні природні явища у вигляді кліматичних катаклізмів та iниi.

Досліджено, щуо, крім негативних економічних наслідків, глобалізація може мати антисоиіальний характер. Глобалізація фактично руйнує простір і розширює відстані. Сьогодні ключовим фактором для виходу з епідемії $\epsilon$ сочіальна відстань, ізолячія особистості. Карантин діаметрально протилежний «відкритому суспільству», на якому свого часу наполягали прибічники глобалізації та інтеграиіі.

Визначено, щзо міжнародний туризм є наслідком глобалізаційних процесів та формою міжнародного руху людських ресурсів, має масовий характер $i$ є однією із провідних високоприбуткових та найбільш динамічних галузей світового господарства.

Виявлено, що глобалізація дає можливість для розвитку різних видів туризму, у тому числі професійно-ділового, культурного, спортивного, медичного, оздоровчого. Зокрема, лікувально-оздоровчий туризм - один із вагомих факторів формування сочіальної безпеки країни за рахунок зміцнення здоров'я населення, поповнення державного бюджету, залучення іноземних інвестицій у спільні медичні проєкти. Для створення позитивного медичного іміджу уряди багатьох країн розробляють нащіональні програми розвитку медичного туризму та виділяють кочти на його становлення.

Важливою метою міжнародного туризму є подорожі професійно-ділового характеру та «бізнес-туризм», серед яких провідне місие займають поїдки на міжнародні ярмарки $i$ виставки.

У прочесі аналізу за названою проблематикою використано загальнонаукові методи: історико-логічний, аналізу та синтезу, порівняльний, групування та ін.

Ключові слова: соціально-економічний розвиток, державна підтримка, міжнародний туризм, глобалізація, медичний туризм, професійно-діловий туризм, онлайн-виставки.

Табл.: 6. Літ.: 17. 


\title{
SOCIO-ECONOMIC ASPECTS OF DEVELOPMENT OF INTERNATIONAL TOURISM ARE UNDER ACT OF FACTORS OF GLOBALIZATION
}

\author{
GOLOVNYA Olena, \\ Doctor of Economic Sciences, \\ Associate Professor of the Department of International Management, \\ Hotel and Restaurant Business and Tourism, \\ Vinnytsia National Agrarian University \\ (Vinnytsia)
}

The impact of globalization on the socio-economic development of the world and Ukraine is traced. The negative consequences of the process of globalization have been that it has become a huge challenge for humanity. According to the author, the biggest threats to the modern world include: the flow of excessive information, which often turns into information attacks; international terrorism, which threatens international tourism and the safe socio-economic development of many countries; negative natural phenomena in the form of climatic cataclysms and others.

It has been studied that, in addition to the negative economic consequences, globalization can have an antisocial character. Globalization is actually destroying space and widening distances. Today, the key factor in overcoming the epidemic is social distance, the isolation of the individual. Quarantine is diametrically opposed to the "open society» that globalization and integration advocated at the time.

It is determined that international tourism is a consequence of globalization processes is a form of international movement of human resources, has a mass character and is one of the leading highly profitable and most dynamic sectors of the world economy.

It is revealed that globalization provides an opportunity for the development of various types of tourism, including professional and business, cultural, sports, medical, health tourism. In particular, health tourism is one of the important factors in shaping the country's social security by strengthening the health of the population, replenishing the state budget, and attracting foreign investment in joint medical projects. To create a positive medical image of the country, the governments of many countries develop national programs for the development of medical tourism and allocate funds for its establishment.

An important goal of international tourism is professional and business travel and «business tourism», among which the leading place is occupied by trips to international fairs and exhibitions.

In the process of analysis on these issues used general scientific methods: historical and logical, analysis and synthesis, comparative, grouping, etc.

Keywords: socio-economic development, state support, international tourism, globalization, medical tourism, professional and business tourism, online exhibitions.

Tabl.: 6. Lit.: 17.

\section{СОЦИАЛЬНО-ЭКОНОМИЧЕСКИЕ АСПЕКТЫ РАЗВИТИЯ МЕЖДУНАРОДНОГО ТУРИЗМА ПОД ВЛИЯНИЕМ ГЛОБАЛИЗАЦИОННЫХ ФАКТОРОВ}

ГОЛОВНЯ Е.М., доктор экономических наук, доцент кафедры менеджмента внешнеэкономической деятельности, гостинично-ресторанного дела и туризма, Винницкий национальный аграрный университет 
Прослежено влияние глобализации на социиально-экономическое развитие мира и Украины. Негативными последствиями прочесса глобализачии стало то, что он стал огромным вызовом для человечества. По мнению автора, к наибольшим угрозам современного мира следует отнести: поток избыточной информачии, которая часто превращается в информационные атаки; международный терроризм, который угрожает международному туризму и безопасному сочиально-экономическом развитии многих стран; негативные природные явления в виде климатических катаклизмов и другие.

Доказано, что, кроме негативных экономических последствий, глобализачия может иметь антисоциальный характер. Глобализаџия фактически разрушает пространство и расширяет расстояния. Сегодня ключевым фактором для выхода из эпидемии является социальное расстояние, изолящия личности. Карантин диаметрально противоположный «открытому обществу», на котором в свое время настаивали сторонники глобализации и интеграции.

Определено, что международный туризм следствием глобализационных процессов является формой международного движения человеческих ресурсов, имеет массовый характер и является одной из ведущих высокодоходных и наиболее динамичных отраслей мирового хозяйства.

Выявлено, что глобализачия дает возможность для развития различных видов туризма, в том числе профессионально-делового, культурного, спортивного, медицинского, оздоровительного туризма. В частности, лечебно-оздоровительньіи туризм - один из весомых факторов формирования сочиальной безопасности страны за счет укрепления здоровья населения, пополнение государственного бюджета, привлечения иностранньх инвестиций в совместные медицинские проекты. Для создания положстельного медицинского имиджа страны правительства многих стран разрабатывают национальные программы развития медицинского туризма и выделяют средства на его становление.

Важной иелью международного туризма являются путешествия профессиональноделового характера и «бизнес-туризм», среди которых ведущее место занимают поездки на международные ярмарки и выставки.

В прочессе анализа по названному проблематикой использовань общенаучные методы: историко-логический, анализа и синтеза, сравнительный, группировки и др.

Ключевые слова: социально-экономическое развитие, государственная поддержка, международный туризм, глобализация, медицинский туризм, профессионально-деловой туризм, онлайн-выставки.

Табл.: 6. Лит.: 17.

Постановка проблеми. 3 погляду етимології «глобальний» (від англ. global - глобальний, всеосяжний) - це такий, що охоплює увесь світ та всі аспекти його життя. Результат глобалізації знаходить вияв у світовому економічному просторі, політичних, фінансових, міжнародних відносинах. Поняття «глобалізація» увійшло в науковий обіг у $80-\mathrm{x}$ рp. XX ст. й відображає структурні та фундаментальні економічні перетворення, має трансформаційний характер, тісно пов'язане зі суспільними відносинами, впливає на формування соціально зорієнтованої постіндустріальної світової цивілізації.

Кількісними характеристиками глобалізації визнано збільшення світового експорту та його частки у ВВП країн світу, величезне зростання прямих іноземних інвестицій, потоків капіталу, щорічного обороту на валютних ринках, обсягів міжнародного банківського кредитування, туризму, міграції робочої сили, тривалості телефонних розмов, ролі Інтернету, засобів масової інформації, а отже, небачене зростання обміну ідеями, інформацією, поширення взаємодії і спілкування громадських організацій, простих людей [17, с. 118]. 
Одним із виявів глобалізації $\epsilon$ розвиток міжнародної туристичної індустрії, яка $\epsilon$ однією із рушійних сил, виділяється з-поміж суспільних елементів глобальної економіки, характеризується високою динамікою зростання та високим потенціалом розвитку.

Аналіз останніх досліджень i публікацій. Взаємозв'язку питань глобалізації і пов'язаних із нею глобальних викликів та еволюції соціальноекономічних складових суспільства останнім часом присвячується все більша кількість наукових досліджень та публікацій - як індивідуальних, так і колективних. Науково-теоретичним та практичним аспектам розвитку економіки країн в умовах глобалізаційних змін присвячені численні наукові дослідження Денисова О.С. [3], Дулина І. С. [5], Парахонського Б.О. [10], Прилуцького А.М. [11], Різника В.В. [12] та багатьох інших.

Формулювання цілей статті. Варто визнати, що більшість досліджень, які присвячені проблемі взаємозв'язку глобальних процесів та еволюції економічних систем, не приділяють належної уваги новітнім глобальним викликам. Важливим $€$ виявлення впливу новітніх глобальних можливостей та викликів, які з'являються в тісному зв'язку із трансформаціями до інших форм світової та національної економічних систем і еволюцією суспільних цінностей, які $\epsilon$ необхідними факторами такого системного переходу.

Тому метою статті є наукове обгрунтування теоретичних і практичних засад розвитку міжнародного туризму під впливом глобалізаційних чинників.

Виклад основного матеріалу дослідження. У сучасних умовах функціонування світової економіки інтенсивного розвитку набуває ринок послуг. Одним із найважливіших, динамічно зростаючих напрямів, що входять до його структури, $є$ туристична індустрія. Це пов'язано з підвищенням впливу останньої на розвиток міжнародних зв'язків, пожвавлення економічного стану країн та окремих регіонів, а також із можливістю поповнення валютних надходжень країн світу. Її значення у світовому масштабі постійно зростає.

У той же час у туризмі $є$ своя специфіка. Тут має місце торгівля як послугами, так і товарами (за оцінками фахівців, частка послуг у туризмі становить $75 \%$, товарів - 25\%), а також особливий характер споживання туристичних послуг та товарів на місці їх виробництва, більш того, у певній ситуації.

Глобалізаційні фактори є тими факторами, за рахунок яких відбувається поширення безпосередніх i опосередкованих зв'язків між суб'єктами економічної діяльності всіх країн світу, формування єдиної (глобальної) для всього світового суспільства системи світогосподарських зв'язків.

Регіоналізація, 3 одного боку, стимулює процеси економічного об'єднання різних країн, але, 3 іншого боку, гальмує процеси світової глобалізації, підсилюючи відособленість окремих економічних угрупувань, а разом із тим протиріччя і конкуренцію між ними. Глобалізація - це неминуче явище сучасності, яке можна пригальмувати засобами економічної політики, але яке неможливо зупинити чи скасувати, адже це імперативна вимога сучасного суспільства та науково-технічного прогресу. Економічні зв'язки перетворюються в провідний фактор прогресу господарських комплексів. У 
таких умовах загострюється конкуренція між провідними підприємствами, зростає залежність країни від розвитку світової глобалізації. Поряд із прибічниками глобалізації сформувалася течія альтерглобалістів, які виступають за глобалізацію нових можливостей, за глобалізацію знань.

Процеси глобалізації набувають стихійного характеру і випереджають соціально-культурні та інші види міжнаціональної взаємодії, що призводить до різкого росту соціальних витрат в усіх сферах життєдіяльності суспільства, включаючи сферу зайнятості, демографічні процеси, якість життя та соціальне забезпечення. Таким чином, процес глобалізації може мати антисоціальний характер [2, с. 9].

Разом із тим, глобалізація за допомогою індустрії туризму сприяє взаємодії народів, створюючи таким чином можливості для об'єднання населення різних країн відповідно до особистих потреб та інтересів: олімпійські ігри, чемпіонати з футболу, фестивалі, оздоровлення та відпочинок, масові видовищні заходи (карнавальні святкування, спеціалізовані виставки).

Активним учасником індустрії туризму є Україна.

Таблиия 1

Кількість туристів, обслуговуваних туроператорами та турагентами, за видами туризму в Україні, осіб

\begin{tabular}{|c|c|c|c|c|}
\hline \multirow[b]{2}{*}{ Роки } & \multirow{2}{*}{$\begin{array}{c}\text { Кількість туристів, } \\
\text { обслуговуваних } \\
\text { туроператорами та } \\
\text { турагентами, усього }\end{array}$} & \multicolumn{3}{|c|}{ У тому числі } \\
\hline & & $\begin{array}{c}\text { в'їзні } \\
\text { (іноземні) } \\
\text { туристи }\end{array}$ & $\begin{array}{c}\text { виїзні туристи (подорожі громадян України } \\
\text { та осіб, які постійно проживають на } \\
\text { території України, до інших країн) }\end{array}$ & $\begin{array}{c}\text { внутрішні } \\
\text { туристи }\end{array}$ \\
\hline 2000 & 2013998 & 377871 & 285353 & 1350774 \\
\hline 2005 & 1825649 & 326389 & 566942 & 932318 \\
\hline 2010 & 2280757 & 335835 & 1295623 & 649299 \\
\hline 2011 & 2199977 & 234271 & 1250068 & 715638 \\
\hline 2012 & 3000696 & 270064 & 1956662 & 773970 \\
\hline 2013 & 3454316 & 232311 & 2519390 & 702615 \\
\hline $2014^{1}$ & 2425089 & 17070 & 2085273 & 322746 \\
\hline $2015^{1}$ & 2019576 & 15159 & 1647390 & 357027 \\
\hline $2016^{1}$ & 2549606 & 35071 & 2060974 & 453561 \\
\hline $2017^{1}$ & 2806426 & 39605 & 2289854 & 476967 \\
\hline $2018^{1}$ & 4557447 & 75945 & 4024703 & 456799 \\
\hline $2019^{1}$ & 6132223 & 87336 & 5525609 & 520336 \\
\hline
\end{tabular}

Дюерело: складено автором за [4]

${ }^{1}$ Без урахування тимчасово окупованої території Автономної Республіки Крим, м. Севастополя та тимчасово окупованих територій у Донецькій та Луганській областях.

Протягом 2000-2019 pp. кількість українських туристів, які обслуговувались туроператорами та турагентами значно коливалася й у 2019 році досягнула максимуму (табл. 1). Серед цілей поїздок провідне місце займає дозвілля та відпочинок.

У таблиці 2 представлений розподіл туристів обслуговуваних, туроператорами та турагентами (юридичні особи) за метою поїздки з України у 2019 році. Таблиця свідчить, що найбільша кількість туристів виїжджали 3 України з метою дозвілля та відпочинку. 
Таблиия 2

Розподіл туристів обслуговуваних, туроператорами та турагентами (юридичні особи) за метою поїздки з України у 2019 році, осіб

\begin{tabular}{|c|c|c|c|c|c|c|c|c|}
\hline \multirow[b]{2}{*}{$\begin{array}{l}\text { № } \\
3 / \text { ח }\end{array}$} & \multirow[b]{2}{*}{ Показник } & \multirow[b]{2}{*}{ Усього } & \multicolumn{6}{|c|}{ Мета поїздки } \\
\hline & & & $\begin{array}{c}\text { службова, } \\
\text { ділова, } \\
\text { навчання }\end{array}$ & $\begin{array}{l}\text { дозвілля, } \\
\text { відпочинок }\end{array}$ & лікування & $\begin{array}{c}\text { спортивний } \\
\text { туризм }\end{array}$ & $\begin{array}{c}\text { спеціалізо } \\
\text {-ваний } \\
\text { туризм }\end{array}$ & інше \\
\hline 1 & $\begin{array}{l}\text { Кількість туристів } \\
\text { у тому числі } \\
\text { обслуговано }\end{array}$ & 3957623 & 211794 & 3671415 & 61303 & 3352 & 1821 & 7938 \\
\hline 2 & туроператорами & 2351338 & 165609 & 2136059 & 42724 & 1934 & 1256 & 3756 \\
\hline 3 & турагентами & 1606285 & 46185 & 1535356 & 18579 & 1418 & 565 & 4182 \\
\hline 4 & $\begin{array}{l}3 \text { них в’їзних } \\
\text { (іноземних) } \\
\text { туристів }\end{array}$ & 72941 & 8031 & 58914 & 3883 & 235 & 283 & 1595 \\
\hline 5 & виїзних туристів & 3508113 & 72327 & 3413736 & 14554 & 1793 & 1423 & 4280 \\
\hline 6 & $\begin{array}{l}\text { внутрішніх } \\
\text { туристів }\end{array}$ & 376569 & 131436 & 198765 & 42866 & 1324 & 115 & 2063 \\
\hline
\end{tabular}

Джерело: складено автором за [4]

У таблиці 3 висвітлено результати діяльності підприємств у сфері туризму в Україні.

Таблиця 3

\section{Результати діяльності підприсмств у сфері туризму}

в Україні, тис. грн.

\begin{tabular}{|c|c|c|c|c|c|c|c|}
\hline \multirow{2}{*}{$\begin{array}{l}\text { № } \\
3 / \Pi\end{array}$} & \multirow{2}{*}{ Показник } & \multicolumn{5}{|c|}{ Роки } & \multirow{2}{*}{$\begin{array}{l}\text { Відхилення, } \\
\text { +/- } 2019 \text { p. } \\
\text { до } 2015 \text { р. }\end{array}$} \\
\hline & & 2015 & 2016 & 2017 & 2018 & 2019 & \\
\hline 1 & $\begin{array}{l}\text { Дохід туроператорів } \\
\text { від надання } \\
\text { туристичних послуг }\end{array}$ & 4233712,6 & 10983160,1 & 17917371,6 & 20307544,1 & 31160995,2 & 26927282,6 \\
\hline 2 & $\begin{array}{l}\text { Дохід турагентів від } \\
\text { надання туристичних } \\
\text { послуг }\end{array}$ & 760749,2 & 921012,6 & 1049132,4 & 1216365,6 & 1432601,4 & 671852,2 \\
\hline 3 & $\begin{array}{l}\text { Дохід суб’єктів, що } \\
\text { здійснюють } \\
\text { екскурсійну діяльність } \\
\text { від надання } \\
\text { туристичних послуг }\end{array}$ & 20887,4 & 31509,0 & 56125,2 & 102011,2 & 106579,4 & 8569,2 \\
\hline
\end{tabular}

Джерело: складено автором за [14]

Глобалізація дає можливість для розвитку різних видів туризму, у тому числі медичного та оздоровчого. Медичний туризм - один із вагомих факторів розвитку галузі охорони здоров'я, поповнення державного бюджету, залучення іноземних інвестицій і створення позитивного іміджу країни. Медичний туризм - це діяльність, пов'язана 3 організацією медичного обслуговування пацієнтів далеко за межами місця їхнього постійного проживання. Причому пацієнти можуть їздити в медичні заклади як усередині країни (внутрішній медичний туризм), так і далеко за кордон (міжнародний медичний туризм).

Багато «медичних туристів» користуються можливістю поєднати медичне обслуговування з відпочинком на курортах, в оздоровчих, SPA i Wellness-центрах. Із кожним роком медичний та оздоровчий туризм набуває все 
більшої популярності, особливо серед жителів США, Канади та країн Західної Європи. Наприклад, у США кількість людей, які не мають повноцінної медичної страховки, перевищує 50 мільйонів чоловік. У більшості населення медична страховка не покриває лікування хронічних захворювань, операції, повноцінне стоматологічне лікування та протезування. Тому багато американців вважають за краще проходити такі види лікування за кордоном.

Незважаючи на те, що громадянам Канади, Великобританії, Швеції держава покриває до 90\% вартості медичних послуг, щоб потрапити до необхідного медичного фахівця або на планову діагностичну процедуру (наприклад, ультразвукову діагностику) іноді доводиться чекати декілька місяців. Середній період очікування планового оперативного втручання в цих країнах складає близько двох років. Тому пацієнти часто вибирають медичні заклади країн Азії та Східної Свропи, у яких можна отримати необхідні медичні послуги відразу і навіть у комфортніших умовах, ніж на Батьківщині.

Нерідко пацієнти просто змушені займатися міжнародним медичним туризмом, оскільки не можуть отримати окремі медичні послуги у своїй країні через нормативні заборони та обмеження. Багато пацієнтів із проблемами безпліддя з Італії, Німеччини, країн Скандинавії їдуть у клініки України та Індії з питань застосування окремих методів допоміжних репродуктивних технологій (сурогатне материнство, донорство ооцитів).

Медичний туризм відкрили для себе і жителі України. Сьогодні поїздки українців на лікування та діагностику в медичні заклади Західної Європи, США, Ізраїлю або Туреччини стали досить звичним явищем.

Щороку Туреччину відвідують майже 1 млн іноземців, які витрачають на лікування близько 10 млрд дол. Рекламою і продажем послуг займається спеціальне агентство, котрому держава виділяє кошти на рекламу і виплачує бонуси. У Міністерстві охорони здоров'я Туреччини створено окремий відділ із розвитку медичного туризму. Міністерство уклало угоди з низкою країн, які постійно спрямовують пацієнтів у турецькі лікувальні заклади.

Останніми роками Україна бере активну участь у розвитку медичного туризму на глобальному рівні. Коли у 2013 році було створено Всесвітню асоціацію медичного туризму (Global Healthcate Travel Council), Україна стала однією із країн-засновниць. Зараз до Global Healthcate Travel Council входять профільні асоціації 56 країн [8].

У 2019 році з метою лікування Україну відвідали майже 65 тис. медичних туристів. Оскільки середній чек на медичні послуги становить близько 2,5 тис дол, прибуток України сягає приблизно 162 млн дол. Ще близько 60 млн дол. - дохід від супутніх послуг (проживання в готелях, харчування, екскурсійні послуги для пацієнтів та членів їхніх родин тощо). При цьому кількість туристів, які відвідали Україну з метою оздоровлення, більше ніж удвічі перевищує показники лікувального туризму. Наприклад, тільки курорт Трускавець за 2019 рік прийняв близько 40 тис. іноземців, із яких понад 40\% гості з Польщі. Безперечно, витрати тільки на оздоровлення - менші, аніж на лікування. Але якщо врахувати весь прибуток держави від лікувального й оздоровчого туризму, то вийде майже 300 млн дол. 
Основними напрямками в’їзного медичного туризму в Україну $є$ стоматологія та лікування безпліддя. Також $\epsilon$ інтерес іноземних пацієнтів до напрямів відновної медицини (наприклад, Міжнародна клініка реабілітації та реабілітаційний центр «Еліта» у Трускавці), офтальмології, кардіології (Київський міський центр серця і Центр дитячої кардіохірургії в Києві), лікування стовбуровими клітинами.

Парадоксом процесу глобалізації стало те, що він, розвиваючись чималою мірою під впливом чинників пошуку більш ефективних відповідей на зростання глобальних викликів, сам став величезним викликом для людства. Чим раніше світове товариство усвідомить існування глобальних загроз та почне вживати систематичних запобіжних заходів, тим раніше буде перерваний руйнівний взаємозв'язок між глобальними викликами та наслідками у вигляді глобальних катастроф.

Сьогодні на глобальну спустошливу силу перетворюється міжнародний тероризм, що загрожує не лише міжнародному туризму, а й безпечному соціально-економічному розвитку багатьох країн. Внаслідок глобалізаційних процесів у сучасних умовах тероризм зазнає істотних якісних змін i перетворюється на серйозну загрозу не тільки для окремих країн, але і для світової безпеки загалом.

Тероризм становить загрозу для міжнародного простору та використовує можливості глобалізації економічних, політичних, інформаційних процесів. Терористи мають у своєму розпорядженні сучасні зразки зброї та військової техніки, використовують інформаційні технології та можливості розгалуженої банківської системи.

Серйозну небезпеку для міжнародної системи та безпеки окремих держав створює глобальна терористична мережа. Насамперед, це зумовлюється активним прагненням терористичних організацій отримати доступ до новітніх ядерних, біологічних, бактеріологічних, інформаційних технологій, що особливо небезпечно на тлі відкритості сучасного суспільства, надмірної вразливості життєво важливих основ суспільного буття та техногенної насиченості сучасної екосфери [10, с. 29].

Рівень терористичної загрози в Україні оцінений як «високий». Про це йдеться в оприлюдненій доповіді Інституту економіки і миру щодо глобального індексу тероризму (GTI) за 2018 рік [16].

За рейтингом, складеним експертами цього аналітичного центру щодо індексу тероризму за 2019 рік (з урахуванням даних за 2018-й), Україна посідає 21-ше місце серед 163 країн світу з показником 6,048, що класифікується як «висока» терористична небезпека. Водночас порівняно 3 попереднім роком держава покращила свої позиції (знизилася у рейтингу небезпеки на чотири сходинки). Серед головних тенденцій глобального індексу тероризму за 2018 рік експерти відзначають зменшення майже на третину - на 27\% кількості летальних випадків від скоєних терактів (загинули 18814 осіб), порівняно з попереднім роком, а також у контексті найбільшого зростання у 2014-му. 
За глобальним індексом тероризму (GTI) у першій десятці країн із найвищою терористичною загрозою визначені Ірак, Афганістан, Нігерія, Сирія, Пакистан, Сомалі, Індія, Смен, Сгипет та Філіппіни [16].

За експертними висновками, 99\% терактів із летальними наслідками було скоєно у країнах, що втягнені у конфлікти або де застосовується політичний терор високого рівня. Глобальні економічні збитки, завдані у результаті терористичної діяльності, як ідеться у дослідженні, оцінюються у 2017 році у 52 млрд дол., що засвідчує зменшення на 42\% порівняно з 2016-м.

Серед країн Західної Свропи покращення на 75\% щодо глобального індексу тероризму відзначено у Франції, Бельгії та Німеччині. Серед основних способів та засобів скоєння терористичних нападів найбільше застосовувалися вибухові пристрої та зброя. Серед деяких інших країн за глобальним індексом тероризму слід відзначити США (20-те місце у рейтингу, рівень загрози «високий», ситуація погіршилася на 12 пунктів), Росію (34-те місце, рівень загрози «низький», ситуація покращилася на один пункт).

Також заслуговує на увагу той факт, що заключне місце рейтингу із оцінкою «відсутності терористичної загрози» посідає Туркменістан. Серед найбільш активних та небезпечних терористичних організації, які діють у світі, експерти назвали «Боко Харам», «Аль-Шабаб», «Талібан», а також ІДІЛ [16].

Ще одна загроза, з якою зіткнувся увесь світ, пандемія коронавірусу. Цей вірус як медично «заразний», так і «заразний» 3 економічного погляду.

Жодна $з$ країн не була повністю готовою до пандемії. Згідно з рейтингом Глобального індексу безпеки здоров'я (Global Health Security), Україна в цьому рейтингу перебуває на 94-й позиції зі 195 країн. Глобальний індекс безпеки здоров'я представляє результати оцінки можливостей глобальної охорони здоров'я у 195 країнах, підготовлених Центром охорони здоров'я Джонса Хопкінса, Ініціативою ядерної загрози (NTI) та відділом економічної розвідки (EIU). Звіт складається на основі опитувальника 3140 питань, організованих за 6 категоріями, 34 показниками та 85 субіндикаторами.

Серед 6 категорій виділяють: профілактику: запобігання виникненню або вивільнення збудників хвороб; виявлення та звітність: ранне виявлення та повідомлення про епідемії, що становлять потенційний міжнародний інтерес; швидке реагування: швидка реакція на пом'якшення поширення епідемії та їх пом'якшення; систему охорони здоров'я: достатня та міцна система охорони здоров'я для лікування хворих та захисту медичних працівників; відповідність міжнародним нормам: зобов'язання щодо поліпшення національної спроможності, планів фінансування для усунення прогалин та дотримання глобальних норм; ризикове середовище: загальне ризикове середовище та вразливість країни до біологічних загроз.

Таблиця 4 демонструє, що найбільш підготовленою країною до епідемій та пандемій є США.

У світі у 2020 році число міжнародних туристичних прибуттів скоротилося на 1 млрд або на 74\% через пандемію коронавірусу і пов'язаних із нею повсюдних обмежень на поїздки. Експортні доходи від туризму у світі скоротилися на 1,3 трлн дол. США, що в 11 разів перевищує втрати в сфері 
міжнародного туризму, які були пов'язані з глобальною економічною кризою 2009 року. Глобальну світову кризу 2008-2009 років спричинило банкрутство, злиття або консервація декількох великих американських фінансових фірм. У той період світ вступив в глобальну фазу загального зниження економічної активності, яка викликала широке скорочення бізнесу, зростання безробіття $\mathrm{i}$ скорочення державних доходів.

Таблиия 4

Готовність країн до епідемій та пандемій, бали

\begin{tabular}{|c|c|c|c|c|c|}
\hline \multicolumn{2}{|c|}{$\begin{array}{c}\text { Найвища готовність, } \\
\text { 100-67 балів }\end{array}$} & \multicolumn{2}{c|}{$\begin{array}{c}\text { Середня готовність, } \\
\text { 66-33 балів }\end{array}$} & \multicolumn{2}{c|}{$\begin{array}{c}\text { Найнижча готовність, } \\
\text { 32-0 балів }\end{array}$} \\
\hline Країна & Бали & Країна & Бали & Країна & Бали \\
\hline США & 83,5 & Туреччина & 52,4 & Туркменістан & 31,8 \\
\hline Велика Британія & 77,9 & Сербія & 52,3 & Маршалові острови & 18,2 \\
\hline Нідерланди & 75,6 & Румунія & 45,8 & Північна Корея & 17,5 \\
\hline Австралія & 75,5 & Росія & 44,3 & Сомалі & 16,6 \\
\hline Канада & 75,3 & Україна & 38,0 & Екваторіальна Гвінея & 16,2 \\
\hline
\end{tabular}

Джерело: складено автором за [6]

У звіті Всесвітньої туристичної організації ООН (UNWTO) констатується, що 2020 рік став найгіршим для туризму за всю історію спостережень. У ньому наголошується також, що криза поставила на межу виживання від 100 до 120 млн робочих місць у туризмі, багато з яких - у малому і середньому бізнесі.

Відновити довіру споживачів може, як вважають у UNWTO, лише поступове вакцинування, що буде сприяти ослабленню обмежень і нормалізації ситуації. Поки ж організація погіршила прогноз щодо термінів відродження міжнародного туризму.

За даними UNWTO, представники туристичної галузі очікують відновлення передусім туризму під відкритим небом, а також внутрішнього туризму. Більшість експертів (43\%) не очікують повернення туризму до показників 2019 року до 2023 року, 41\% - до 2024 року. Сценарії, підготовлені UNWTO, показують, що на повне відновлення туризму знадобиться від 3,5 до 6 років.

Останнє опитування експертів UNWTO показує неоднозначний прогноз на 2021 рік: 45\% із них очікує поліпшення ситуації порівняно з 2020 роком, $25 \%$ - повторення такого ж результату, 30\% - погіршення. Загальні перспективи відновлення економіки у 2021 році теж погіршилися. Зараз 50\% експертів очікують, що воно відбудеться тільки у 2022 році, тоді як у жовтні 2020 року таких було лише $21 \%$.

За останніми даними Всесвітньої туристської організації (UNWTO), поява нових варіантів вірусу Covid-19 спонукала уряди багатьох країн скасувати ослаблення обмежень на поїздки, а також повністю закрити в'їзд туристам.

Доповідь UNWTO про обмеження на поїздки показує, що з 69 напрямків, де кордони повністю закриті для туристів, 30 знаходяться в АзіатськоТихоокеанському регіоні, 15 - в Свропі, 11 - в Африці, 10 - в Америці і 3 - на Близькому Сході. Ще 73 країни закрили свої кордони частково, 703 них 
вимагають від в'їжджаючих туристів проходження карантину або негативний тест на Covid-19.

За даними UNWTO, найбільше від пандемії постраждав туризм в Азіатсько-Тихоокеанському регіоні, де діють особливо суворі обмеження на поїздки. Число міжнародних прибуттів тут знизилося у 2020 році на 300 млн або 84\%. На Близькому Сході і Африці спад склав 76\% і 70\%, у Європі - 71\%. При цьому на європейському континенті зафіксовано найбільше падіння числа поїздок в абсолютному вираженні порівняно з 2019 роком - 221 млн. У Північній і Південній Америках зниження числа прибуттів іноземних туристів склало 69\% (табл. 5.) [15].

Таблиия 5

Зміна кількості міжнародних туристів за регіонами світу

\begin{tabular}{|c|c|c|}
\hline Регіон & 2019 рік & 2020 рік \\
\hline $\begin{array}{l}\text { Північна та } \\
\text { Південна Америка }\end{array}$ & 220 млн (+2\% порівняно з 2018 роком) & -79 \% порівняно з 2019 роком (69 млн осіб) \\
\hline Європа & 745 млн (+4\% порівняно з 2018 роком) & -71 \% порівняно з 2019 роком (221 млн осіб) \\
\hline Африка & 73 млн (+6\% порівняно з 2018 роком ) & -70 \% порівняно з 2019 роком (17,8 млн осіб) \\
\hline Близький Схід & 61 млн (+2\% порівняно з 2018 роком ) & -76 \% порівняно з 2019 роком (16 млн осіб) \\
\hline Азія та Тихий океан & 361 млн (+4\% порівняно з 2018 роком) & -84 \% порівняно з 2019 роком (57 млн осіб) \\
\hline
\end{tabular}

Важливою метою міжнародного туризму $€$ туристичні подорожі професійно-ділового характеру, серед яких провідне місце займають поїздки на міжнародні ярмарки і виставки. Міжнародні виставки, ярмарки, аукціони, які відвідують мільйони туристів - досить прогресивна форма спілкування і $\epsilon$ одним із найбільш ефективних маркетингових інструментів для бізнесу.

Замість поняття «бізнес-туризм» часто використовується англійський термін-абревіатура - МICE, що точно відображає структуру цього виду туризму: Meetings/incentives/conferences/exibitions, і в перекладі означає: ділові зустрічі/інсентив - туризм/конференції/виставки.

У період пандемії їх проведення виявилося під табу, але частина перейшла в діджитал-формат і все ж відбулася, позначивши перспективу на майбутнє. Виставкова діяльність потрапила під карантинні обмеження в усьому світі, і кожна країна, залежно від того, як перенесла першу хвилю пандемії, приймала рішення, коли відновити виставкову активність.

Утім, хоча більшість виставок, запланованих на час карантину, було перенесено, вимушена загальносвітова ізоляція стимулювала розвиток нового формату - віртуального або онлайн. Будь-яка виставка - це насамперед комунікації: люди знайомляться один із одним і вирішують, чи буде їм комфортно співпрацювати надалі. Цей формат ділового спілкування буде ще довго актуальним.

Найефективніші і масштабні онлайн-виставки зараз проходять у Китаї. Наприклад, Кантонська - найбільший у світі китайський ярмарок імпорту та експорту. Виставка проходила під час карантину на онлайн-платформі, розробка якої коштувала 2 млн дол. Оплату платформи, хостингу та стрімінгу взяв на себе китайський уряд. До кінця 2021 року Китай не налаштований 
приймати закордонні делегації, соціальна дистанція зараз у пріоритеті. Тому всі охочі підприємці, які зацікавлені в експорті або імпорті товарів, можуть самі спробувати вивчити особливості електронної комерції у Китаї або скористатися послугами посередника. У кожного виставкового та торговельного майданчика свої вимоги до торгових марок, до подачі товару і особливості, тому консультації фахівців хоча б спочатку будуть не зайвими.

Варто виділити кілька форматів онлайн-виставок, які проходили під час карантину і будуть продовжувати розвиватися в найближчій перспективі.

Віртуальна виставка виглядає як віртуальна гра із зображенням стендів, по яких гравець ходить, розглядає стенди, за бажання клацає на чоловічкаменеджера, який повинен відразу виходити на зв'язок за допомогою Zoom або інших інструментів. Прикладом такої виставки є ярмарок вакансій в авіаційній $\mathrm{i}$ космічній індустрії Німеччини SkyForward.

Виставка-маркетплейс $\epsilon$ каталогом із продукції експонентів. Її відмінність у якісній рубрикації за продуктами в каталозі, порівняно з інтернет-магазином. Завдяки вбудованим фільтрам пошук потрібного експонента значно скорочується. Прикладом слугує вітчизняна постійно діюча взуттєва виставка ExpoShoes online, на якій представлені тільки українські виробники.

Гібридна виставка - коли є формати офлайн і онлайн. В онлайні за допомогою matchmaking (штучний інтелект, який через опис продукту і запит на купівлю продукту підбирає продавця і покупця) відвідувач визначає коло тих, з ким хоче поспілкуватися, йде на реальний стенд спілкуватися і «мацати» продукт. В онлайн-форматі зустріч відбувається у віртуальній онлайн-кімнаті виставкової платформи або через внутрішньоплатформенний месенджер. Наприклад, уже згадана Кантонська експортно-імпортна виставка.

Виставка-вебінар - нон-стоп ідуть презентації продуктів відповідно до встановленого заздалегідь розкладу. Вони можуть розділятися на потоки за трендами. Наприклад, CosmoProf Bologna [1].

В Україні створена Національна туристична організація України (НTO), мета якої спрямована на приведення сектора туризму до найбільш збалансованої і стійкої моделі розвитку. Мета НТО - створити постійно діючу мережу-платформу об'єднання регіональних, міських і галузевих туристичних організацій для підвищення якості національного туристичного продукту, розвитку системи професійних знань і підготовки фахівців, а також всього комплексу маркетингу туристичного бренду України на внутрішньому i глобальному ринку [9].

Діяльність НТО носить системний і комплексний характер, завжди враховує найсучасніші глобальні тенденції, міжнародні стандарти та спрямована на максимально швидке впровадження кращих світових практик у секторі туризму України. Протягом 2021 року НТО продовжила організовувати тематичні нетворкінг сесії, проводити ділові, освітні та маркетингові заходи, розробляти стандарти якості та протоколи безпеки, сприяти консолідації та колаборації учасників сектору туризму між собою, з органами влади, закладами освіти і мешканцями міст. 
Так, наприклад, за підтримки НТО був проведений Всеукраїнський конкурс «\#SafeTravels Contest» на засадах партнерства 3 метою сприяння реалізації Глобальної ініціативи WTTC «SafeTravels» і зменшення негативних наслідків поширення пандемії COVID-19 на сферу туризму та гостинності України. Використання бізнесом спеціально розробленого знаку «SafeTravels» дозволяе туристам впізнавати локації, атракції та компанії в усьому світі, як такі, що прийняли і виконують глобальні стандартизовані протоколи охорони здоров'я та гігієни задля того, щоб туристи подорожували безпечно. По всій Україні були відзначені переможці цього конкурсу. Зокрема, переможці конкурсу у Вінницькій області представлені в таблиці 6.

Таблиия 6

\section{Підприсмства Вінницької області, які виконують глобальні стандартизовані протоколи охорони здоров'я та гігієни}

\begin{tabular}{|c|c|c|}
\hline \multicolumn{3}{|r|}{ Для безпечного туризму } \\
\hline $\begin{array}{l}\text { № } \\
\text { 3/ח }\end{array}$ & Сфера діяльності & Перелік підприємств \\
\hline 1 & Готелі і місця розміщення & $\begin{array}{c}\text { Готель «Аристократ», Готель «Франція», Готель «Феріде», Готель } \\
\text { «Затишок», Готель «Fenix», Апартаменти «SmartApart», «Fenix Town» }\end{array}$ \\
\hline 2 & $\begin{array}{c}\text { Туроператори і туристичні } \\
\text { агенції }\end{array}$ & $\begin{array}{c}\text { ТОВ Туристичний оператор «Бомба-тур», ТОВ «Слав'янський тур», } \\
\text { Туристичний Клуб «Бідняжка», юридична особа ТОВ «ТКБ», } \\
\text { ТОВ ВКФ «Сігма-3» }\end{array}$ \\
\hline 3 & Туристичні атракції & $\begin{array}{c}\text { Академія активного відпочинку, Тюбінг-парк Vinny Land, Музей } \\
\text { Науки, Вінницький Планетарій }\end{array}$ \\
\hline 4 & Торгівельні заклади & ТОВ «ТВК Петроцентр» \\
\hline
\end{tabular}

Джерело: складено автором за [9]

Реалізація потенціалу туризму як інструменту сталого та інклюзивного зростання вимагає багатостороннього і багаторівневого підходу, заснованого на тісній співпраці між туристичними та нетуристичними структурами в міських радах та адміністраціях, а також постійну системну та комплексну взаємодію із приватним сектором, місцевим населенням і самими туристами.

Висновки. Туризм $є$ одним із тих секторів всесвітньої економіки, що постраждав найбільше у зв'язку з обмеженнями на пересування, особливо складна ситуація склалася в авіаційній галузі. Саме міжнародний туризм сприяє культурній глобалізації між країнами за допомогою поширення ідей, цінностей у світі з розширенням та збагаченням культурних відносин.

В Україні сьогодні спостерігається значне відставання у темпах впровадження заходів на підтримку туристичного сектору, що ставить під серйозну загрозу конкурентоспроможність галузі на глобальному ринку.

Сектор туризму в Україні не отримав швидкого системного реагування 3 боку уряду у вигляді впровадження можливих заходів на підтримку туристичної галузі, якщо порівнювати із середнім реагуванням і типами заходів, запроваджених урядами сусідніх країн і країн-членів СС. Це ускладнює становище малого та середнього бізнесу, який працює у сфері гостинності, туризму та відпочинку.

Таким чином, під дією багатьох чинників глобалізації, яка несе як позитивні впливи, так і певні загрози, Україна, повинна інтегруватися у 
світовий соціально-економічний та політичний простір. Перед державою постає завдання визначення своїх конкурентних переваг, щоб на належному рівні конкурувати з іншими державами на світовому ринку.

\section{Список використаних джерел}

1. Віртуальні виставки: долучаємося до тренда. URL: https://www.aval.ua/biznesu/blog/virtualni-vistavki-doluchayemosya-do-trenda-255 (дата звернення: 19.03.2021).

2. Головня О.М. Вплив глобалізаційних процесів на соціально-економічне зростання України: оцінка загроз та можливостей. Економіка та держава. 2010. № 6. С. 6-9.

3. Денисов О.С. Глобалізаційний вимір економічної безпеки держави. Економічний аналіз. 2016. Т. 26 (1). С. 19-27.

4. Державна служба статистики України. Офіційний сайт. URL: http://www.ukrstat.gov.ua/ (дата звернення: 11.03.2021).

5. Дулин І.С. Вплив глобалізаційних процесів на розвиток міжнародного туризму. Молодий вчений. 2018. №10 (2). С. 786-791.

6. Економічні сценарії: як країни реагують на наслідки коронавірусу URL: https://www.radiosvoboda.org/a/30484006.html (дата звернення: 14.03.2021).

7. Концептуальная записка: COVID-19 и перестройка сектора туризма. OOH. 2020. 29 c. URL: https://www.un.org/sites/un2.un.org/files/policy_ brief_covid-19_and_transforming_tourism_russian.pdf (дата звернення: 11.03.2021).

8. Медичний туризм в Україні: можливості vs реальність. URL: https://www.vz.kiev.ua/medychnyj-turyzm-v-ukrayini-mozhlyvosti-vs-realnist/(дата звернення: 11.03.2021).

9. Національна туристична організація України. URL: http://www.ntoukraine.org/ (дата звернення: 11.03.2021).

10. Парахонський Б.О., Яворська Г.М, Резнікова О.А. Міжнародне безпекове середовище: виклики і загрози національній безпеці України. Київ: НІСД, 2013. 64 c.

11. Прилуцький А.М. Інвестиційні ресурси економіки України в умовах глобалізаційних процесів. Міжнар. наук.-практ. конф. [«Сучасний стан та перспективи розвитку економіки в умовах глобалізаційних процесів»], 1819 квіт. 2019 р. Вінниця : ВНАУ.

12. Різник В.В. Формування підприємливості та нового типу економічного мислення в контексті прогресивної глобалізації. Економічний вісник університету. 2019. Вип. 42. С. 63-69.

13. COVID-19 та наслідки для світового туризму. URL: https://dip.org.ua/yegipet/covid-19-ta-naslidki-dlya-svitovogo-turizmu/ (дата звернення: 21.03.2021).

14. Туристичний барометр України. Київ: Національна туристична організація України. 2020. 203 c. URL: http://www.ntoukraine.org/assets/files/ntoubarometer-2020.pdf (дата звернення: 26.11.2020). 
15. Уніан. Інформаційне агентство. URL: https://www.unian.ua/tourism/ news/10839209 (дата звернення: 26.11.2020).

16. Україна займає 21 місце в світі за рівнем терористичної загрози. URL: https://www.ukrinform.ua/rubric-society/2594563-ukraina-zajmae-21-misce-v-svitiza-rivnem-teroristicnoi-zagrozi.html (дата звернення: 26.12.2020).

17. Чухно А.А. Постіндустріальна економіка: теорія, практика та їх значення для України. Київ: Логос, 2003. 631 с.

\section{References}

1. Virtualni vystavky: doluchaiemosia do trenda [Virtual exhibitions: join the trend]. Retrieved from: https://www.aval.ua/biznesu/blog/virtualni-vistavkidoluchayemosya-do-trenda-255 [in Ukrainian].

2. Golovnya, O.M. (2010). Vplyv hlobalizatsiinykh protsesiv na sotsialnoekonomichne zrostannia Ukrainy: otsinka zahroz ta mozhlyvostei [The impact of globalization processes on the socio-economic growth of Ukraine: assessment of threats and opportunities]. Ekonomika ta derzhava - Economy and state, 6, 6-9 [in Ukrainian].

3. Denysov, O.Ye. (2016). Hlobalizatsiinyi vymir ekonomichnoi bezpeky derzhavy [The globalization dimension of economic security of the state]. Ekonomichnyi analiz - Economic analysis, 26 (1), 19-27 [in Ukrainian].

4. Derzhavna sluzhba statystyky Ukrainy [State Statistics Service of Ukraine]. ukrstat.gov.ua. Retrieved from: http://www.ukrstat.gov.ua/ [in Ukrainian].

5. Dulyn, I.S. (2018). Vplyv hlobalizatsiinykh protsesiv na rozvytok mizhnarodnoho turyzmu [The impact of globalization processes on the development of international tourism]. Molodyi vchenyi - A young scientist, 10(2), 786-791 [in Ukrainian].

6. Ekonomichni stsenarii: yak krainy reahuiut na naslidky koronavirusu [Economic scenarios: how countries react to the effects of coronavirus]. radiosvoboda.org. Retrieved from: https://www.radiosvoboda.org/a/30484006.html [in Ukrainian].

7. Kontseptualnaia zapyska: SOVID-19 y perestroika sektora turyzma [Concept Note: COVID-19 and Tourism Sector Restructuring]. (2020). un.org. Retrieved from: https://www.un.org/sites/un2.un.org/files/policy_ brief_covid19_and_transforming_tourism_russian.pdf [in Ukrainian].

8. Medychnyi turyzm v Ukraini: mozhlyvosti vs realnist [Medical tourism in Ukraine: opportunities vs reality]. vz.kiev.ua. Retrieved from: https://www.vz.kiev.ua/medychnyj-turyzm-v-ukrayini-mozhlyvosti-vs-realnist/ [in Ukrainian].

9. Natsionalna turystychna orhanizatsiia Ukrainy [National Tourist Organization of Ukraine]. ntoukraine.org. Retrieved from: http://www.ntoukraine.org/ [in Ukrainian].

10. Parakhonskyi, B.O., Yavorska, H.M, \& Reznikova, O.A. (2013). Mizhnarodne bezpekove seredovyshche: vyklyky $i$ zahrozy natsionalnii bezpetsi Ukrainy [International security environment: challenges and threats to Ukraine's national security]. Kyiv: NISD [in Ukrainian]. 
11. Prylutskyi, A.M. (2019). Investytsiini resursy ekonomiky Ukrainy v umovakh hlobalizatsiinykh protsesiv [Investment resources of the Ukrainian economy in the context of globalization processes]. Mizhnar. nauk.-prakt. konf. «Suchasnyi stan ta perspektyvy rozvytku ekonomiky v umovakh hlobalizatsiinykh protsesiv» International scientific-practical conference «Suchasnyi stan ta perspektyvy rozvytku ekonomiky $v$ umovakh hlobalizatsiinykh protsesiv» International. scientific-practical conf. "Current state and prospects of economic development in the context of globalization processes». 18-19 kvit. Vinnytsia: VNAU [in Ukrainian].

12. Riznyk, V.V. (2019). Formuvannia pidpryiemlyvosti ta novoho typu ekonomichnoho myslennia $\mathrm{v}$ konteksti prohresyvnoi hlobalizatsii [Formation of entrepreneurship and a new type of economic thinking in the context of progressive globalization]. Ekonomichnyi visnyk universytetu - Economic Bulletin of the University, 42, 63-69 [in Ukrainian].

13. COVID-19 ta naslidky dlia svitovoho turyzmu [COVID-19 and implications for world tourism]. dip.org.ua. Retrieved from: https://dip.org.ua/yegipet/covid-19-ta-naslidki-dlya-svitovogo-turizmu/ [in Ukrainian].

14. Turystychnyi barometr Ukrainy [Tourist barometer of Ukraine]. Kyiv: Natsionalna turystychna orhanizatsiia Ukrainy. (2020). ntoukraine.org. Retrieved from: http://www.ntoukraine.org/assets/files/ntou-barometer-2020.pdf [in Ukrainian].

15. Unian. Informatsiine ahentstvo [UNIAN. News agency]. unian.ua. Retrieved from: https://www.unian.ua/tourism/ news/10839209 [in Ukrainian].

16. Ukraina zaimaie 21 mistse $\mathrm{v}$ sviti za rivnem terorystychnoi zahrozy [Ukraine ranks 21st in the world in terms of terrorist threat]. ukrinform.ua. Retrieved from: https://www.ukrinform.ua/rubric-society/2594563-ukraina-zajmae-21-misce-vsviti-za-rivnem-teroristicnoi-zagrozi.html [in Ukrainian].

17. Chukhno, A.A. (2003). Postindustrialna ekonomika: teoriia, praktyka ta yikh znachennia dlia Ukrainy [Post-industrial economy: theory, practice and their significance for Ukraine]. Kyiv: Lohos [in Ukrainian].

\section{Відомості про автора}

ГОЛОВНЯ Олена Михайлівна - доктор економічних наук, доцент кафедри менеджменту зовнішньоекономічної діяльності, готельно-ресторанної справи та туризму, Вінницький національний аграрний університет (21008, м. Вінниця, вул. Сонячна, 3, e-mail: ellens@ meta.ua).

GOLOVNYA Olena - Doctor of Economic Sciences, Associate Professor of International Management, Hotel and Restaurant Business and Tourism, Vinnytsia National Agrarian University (21008, Vinnytsia, 3 Soniachna str., e-mail: ellens@meta.ua).

ГОЛОВНЯ Елена Михайловна - доктор экономических наук, доцент кафедры менеджмента внешнеэкономической деятельности, гостиничноресторанного дела и туризма, Винницкий национальный аграрный университет (21008, г. Винница, ул. Солнечная, 3, e-mail: ellens@ meta.ua). 